\title{
Review
}

\section{Writing human rights: The political imaginaries of writers of color}

\author{
Crystal Parikh \\ University of Minnesota Press, Minneapolis, \\ 344 pp., ISBN: 978-0816697069
}

Contemporary Political Theory (2019) 18, S137-S140. https://doi.org/10.1057/s41296018-0203-x; published online 9 March 2018

Crystal Parikh's Writing Human Rights: The Political Imaginaries of Writers of Color is a timely and ambitious work that makes an impassioned claim for both reclaiming and problematizing contemporary human rights discourse. As a literary critic with explicitly political concerns, a thinker interested in counter-hegemonic ideas but one who doesn't abandon the quest for ethical life, Parikh issues a challenge to contemporary political theorists interested in thinking through radical critique and racial justice during our reactionary times. Human rights discourse, as has well been documented and thoroughly discussed, is nothing short of complex. On the one hand, since the end of the Second World War, it has been a crucial tool for the most vulnerable people to mobilize against the horrors authoritarianism, domination, exclusion, and violence. On the other hand, it has historically been coopted for dangerous ends - just think of invocations of humanitarian intervention, US's wars for spreading democracy and peace abroad, and all the efforts associated with neoliberal privatization and financial austerity. Critics thus insist that human rights are ineffective at best, or nothing more than instruments of hegemony at worst. They are seen as powerful words on paper that only matter to the extent they are truly secured, but are usually proclaimed by states to mask their own geopolitical interests in the pursuit of free market capitalism and political order - rather than democracy. The upshot here is that human rights have very little to do with making life more livable for the poor, women, people of color, and the disabled.

Parikh's work insists that such pessimism, while historically justified and intellectually understandable, relies on a narrow notion of human rights. In her view, we haven't fully appreciated the political potential in the meaning of both humanity and rights precisely because we haven't fully engaged the terrain in which these two terms have been most fruitfully explored, namely what she calls

(c) 2018 Macmillan Publishers Ltd., part of Springer Nature. 1470-8914 Contemporary Political Theory Vol. 18, S2, S137-S140 www.palgrave.com/journals 
the 'minor literatures' of writers of color, such as Toni Morrison, Ernest Gaines, Maxine Hong Kingston, Jessica Hagedorn, Chang-rae Lee, and Susan Choi, among others. Parikh's ambition is not to romanticize such minor literatures as inherently radical or emancipatory - or even claim that the ideas embedded within them could be easily applied to politics. Instead, the intention is to show a counter-vision of human rights that emphasizes shared human precariousness, unveiling the fantasy of invulnerability, and endorsing the construction of personal and familial relationships not governed by pernicious ideals of what is socially respectable. Indeed, if human rights discourse relies on a notion of universality but smuggles in a provincialized account of what is properly human (white, American, male, heterosexual, invulnerable), Parikh aims to provincialize such dominant narratives. The aim is to shed light on the ethical viability of that, which is more attentive to difference and pluralism and more capable of addressing suffering and degradation in ways responsive to the citizens for whom human rights are said to matter the most. On the one hand, she writes that 'human rights provide deeply meaningful methods of political and moral imagining, especially for subjects whose recognition by the state is tenuous, if not altogether foreclosed' (p. 1). On the other hand, she emphasizes 'bodily and social vulnerability' and stresses the way 'minor literatures give voice to the complex desires of these subjects' and how they 'mediate the subject's experiences of vulnerability and agency' (p. 6).

Political theorists who read Writing Human Rights will see the work as enacting three main projects: the post-colonial attempt to provincialize American and Western universalism (Dipesh Chakrabarty, Gayatri Spivak), the post-structural critique of power (Michel Foucault, Jacques Derrida), and developing a sense of global responsibility based in shared precariousness (Stephen White, Judith Butler). For these reasons, at a moment when the term 'identity politics' is used by critics to denigrate movements on the left that call for justice for marginalized identities, Parikh's work offers a corrective. Following recent work by critical race theorists, queer theorists, and feminists, an implicit argument of the book is that all politics is, in some sense, based in specific identity standpoints that it often obscures. Put differently, identity, then, is an inescapable source of political claim making, whether or not it is seen as such.

One of the things that makes Writing Human Rights an important work and will surely interest political theorists is Parikh's ability to successfully and effortlessly move between different methodological approaches - literary criticism, US intellectual history, critical race theory, legal theory - without sacrificing intellectual rigor or political purpose. Part of why Parikh's readings are so theoretically generative is that they provide a method to see literature (narrative,

S138 (c) 2018 Macmillan Publishers Ltd., part of Springer Nature. 1470-8914 Contemporary Political Theory Vol. 18, S2, S137-S140 
plot, dialogue) as harboring both critical and normative insights, but also that they express a theoretical imagination that is not bound by traditional argumentative conventions (like didactic claiming or deductive logical reasoning) or simple resolutions. The texts she explores, many of which have been examined by critics before, are given a fresh take. For instance, in the introduction, she reads Toni Morrison's classic novel, Beloved (1987) (based on the nineteenth century historical figure of Margaret Garner), as a work that exposes how 'humanness' is a construction. In the novel, an enslaved person, Sethe, who has no rights is nonetheless considered criminal when she kills her child, Beloved - who also will have no rights - in order to save her from slavery. Sethe sees herself as human, even as her sense of self is haunted by the past and the dangers in the world as a black woman in the post-Reconstruction era. This vulnerability doesn't preclude her from persisting and reconstructing new family networks, as well as attempting to love and be loved.

These themes are continued throughout the book. The first chapter considers how the work of Gaines and Kingston complicates the idea of Afro-Asian solidarity in a way that radicalized the impulse towards global antiracism. Through a reading of novels by Hagedorn and Lee, the second chapter examines how human rights have a life of their own, escaping ideas of humanity found within liberalism. The third chapter, centered on Susan Choi's The Foreign Student, considers how minor literature evokes an idea of vulnerability in ways that expand the right to security and escape narrow ideas of community. The final three chapters zoom in on novels by Julia Alvarez, Jhumpa Lahiri, and Ana Castillo and Aimee Phan to tackle the rights to revolution, to health, and to family in ways that make us rethink ideas about what it means to flourish, and make autonomous choices about the good life.

Despite its overwhelming strengths and clear interest for contemporary political theorists, Writing Human Rights is not primarily a work of traditional political theory. Although Parikh fluidly invokes Arendt, Foucault, Levinas, and Fanon among others throughout, her concern is less with placing minor literature into conversation with American political thought or the Western tradition and more with the boundaries of literary criticism and American studies. For all of the crucial and provocative questions the book generates, it still leaves some unresolved: what would a national or international politics, or even social movements like Black Lives Matter, \#MeToo, or Dakota Access Pipeline protests, based in the minor literature of human rights, look like? Is there a tension between questions of institutional politics (geopolitical interests, grassroots struggle, state activity, and NGO work that tries to advance human rights) and the radical normative project of ethico-political thinking? Answering these questions is, of course, not central to the

(C) 2018 Macmillan Publishers Ltd., part of Springer Nature. 1470-8914 Contemporary Political Theory Vol. 18, S2, S137-S140 S139 
book's success, but they could be taken up in future work that tries to grapple seriously with rethinking key political institutions and discourses that affect people's everyday lives.

Nonetheless, Parikh's work serves as an important model of an engaged and probing mode of writing for our contemporary moment when democratic faith and norms are being thrown into question. Thinking human rights is perhaps more important now than ever before, given the global the rise of authoritarianism, white supremacy, racism, xenophobia, the assault on women's reproductive rights, ongoing war, occupation, torture, and ethnic cleansing. As Writing Human Rights reminds us, however, accepting the spirit behind human rights - justice, equality, self-determination, dignity - does not require succumbing to its dominant formulations.

Alex Zamalin

University of Detroit Mercy, Detroit, MI 48221, USA zamalial@udmercy.edu 